ISSN 0258-7122

Bangladesh J. Agril. Res. 33(3) : 381-389, September 2008

\title{
SEED QUALITY ASSESSMENT OF THREE PHOTO-INSENSITIVE CULTIVARS OF LABLAB BEAN INFLUENCED BY DATE OF SOWING
}

\author{
K.M. KABIR ALAM ${ }^{1}$, M.K.R. BHUIYAN ${ }^{2}$, G.M.A. HALIM ${ }^{3}$, \\ M. ZAKARIA ${ }^{4}$ AND M.J. HOSSAIN ${ }^{5}$
}

\begin{abstract}
Quality of seeds of three cultivars (IPSA Seem-2, BU Seem-3 and IPSA Seem5) of lablab bean (Lablab purpureus L. Sweet) collected from crops planted in three different dates (15 May, 15 July, and 15 September 2003) was assessed in respect of different parameters. The maximum percentage of seeds of cv. IPSA Seem-2 was germinated (95.67) whereas, BU Seem-3 had the maximum electrical conductivity (EC) $(316.06 \mu \mathrm{s} / \mathrm{cm})$ followed by IPSA Seem-5 (261.53 $\mu \mathrm{s} / \mathrm{cm}$ ). The cv. IPSA Seem-2 also had the highest vigour index (VI) (65.04) and coefficient of germination (CG) (58.90). The maximum length of root and shoot was $13.73 \mathrm{~cm}$ and $12.98 \mathrm{~cm}$ in IPSA Seem-5 and IPSA Seem-2, respectively. The percentage of dry matter of root and shoot was the highest for BU Seem-3 (23.68 and 12.15, respectively), whereas, the composite sample of root and shoot of IPSA Seem-2 had the highest value of dry matter (14.54\%). Seeds of September planted crops had better germination percentage (95.67), VI (50.07), CG (47.65), length of root $(13.63 \mathrm{~cm})$, dry matter of root $(24.79 \%)$, shoot (13.34\%) and composite sample (15.14\%). Whereas, seeds of May planted crops had the maximum EC $(388.23 \mu \mathrm{s} / \mathrm{cm})$ and length of shoot $(15.29 \mathrm{~cm})$. Seeds of cv. IPSA Seem-2 collected from September planted crops had the maximum germination percentage (97.75), VI (70.96), CG (64.13), length of shoot (11.41 $\mathrm{cm})$ and dry matter percentage of composite sample of root and shoot (16.58). BU Seem-3 of May planted crops had the maximum EC $(469.78 \mu \mathrm{s} / \mathrm{cm})$. But BU Seem-3 of September planting had the highest dry matter of root of seedling (25.19\%). Seedlings of cv. IPSA Seem-5 planted in September had the highest length of roots $(14.63 \mathrm{~cm})$ and dry matter of shoot $(13.79 \%)$.
\end{abstract}

Key Words: Seed quality, photo-insensitive, dates of planting and lablab bean.

\section{Introduction}

Lablab bean (Lablab purpureans L. Sweet) belongs to the family Papilionaceae, cultivated mainly in winter season in Bangladesh. It is a highly nutritious vegetable. Its green pods provide a good amount of protein in addition to vitamins and minerals (Gopalan et al., 1982).

\footnotetext{
${ }^{1}$ Senior Scientific Officer, TCRC, BARI, Joydebpur, Gazipur-1701, ${ }^{2}$ Senior Scientific Officer, HRC, BARI, Joydebpur, Gazipur-1701, ${ }^{3}$ Asstt. Professor, Dept. of Horticulture, BSMRAU, Salna, Gazipur, ${ }^{4}$ Principal Scientific Officer, HRC, BARI, Joydebpur, Gazipur, Bangladesh.
} 
In Bangladesh, the annual production of vegetable is 1.53 million metric tons (BBS, 2005), which is far below to its actual requirement of $9.21 \mathrm{~m}$ metric tons. The average vegetable consumption in Bangladesh is only $50 \mathrm{~g}$ per head per day, against the actual requirement of $213 \mathrm{~g}$ (AIS, 2007). There is a big gap between the need and supply of vegetable in the country. Moreover, vegetable production is not uniform throughout the year. A serious scarcity of vegetable is observed during summer (May - September). To overcome this problem, there is a critical need for introducing new summer vegetables or developing enough number of year round cultivars of existing vegetables.

Recently, BSMRAU has developed some photo-insensitive cultivars of lablab bean, which performed reasonably well in respect of quality. There is, however, a problem associated with seed production of these cultivars. There are reports (Srivastava et al., 1976) that sowing time is one of the important factors that affect seed quality. Balles et al. (1978) observed that July sowing increased soybean seed viability and vigour compared to May or June sowing, which Castillo et al. (1994) did not find any effect of time of sowing on seed quality of pea seeds. It is not yet known, which is the best time of sowing of seeds during summer for producing quality seeds of lablab bean cultivars capable of year round production. Hence, the experiment was aimed to produce quality seeds of lablab bean cultivars in relation to time of sowing during summer (May to September).

\section{Material and Method}

The quality of seed was evaluated on the basis of some tests, such as germination test, speed of germination, seedling evaluation test, and electrical conductivity test. Three recommended photo-insensitive cultivars of lablab bean (IPSA Seem2, BU Seem-3, IPSA Seem -5) were used in this experiment. Mature seeds of three different sowing dates (15 May, 15 July, and 15 September 2002) were collected for conducting this experiment. For germination test, one hundred seeds of each sample were placed in petridish containing filter paper soaked with distilled water. Each sample was replicated four times. The petridishes were kept at room temperature and observed everyday and continued upto 8 days. A seed was considered to be germinated when seed coat was ruptured, plumule and radicle came upto $2 \mathrm{~cm}$ length. Speed of germination was assessed by Coefficient of germination and vigour index (VI) using the formula developed by Copeland (1976).

Co - efficient of germination $=\frac{100\left(A_{1}+A_{2}+------A_{X}\right)}{A_{1} T_{1}+A_{2} T_{2}+-----A_{X} T_{X}}$ 
Where, $\quad A=$ Number of seeds germinated

$\mathrm{T}=$ Time corresponding to $\mathrm{A}$

$\mathrm{X}=$ Number of days for final count

Seedling evaluation test was done with germinated seeds. Seedling shoot and root length were measured on the $8^{\text {th }}$ day of germination test. Twenty plant samples from ten poly bags were harvested and shoot and root length of individual plant were recorded. The shoots and roots were also dried at $70^{\circ} \mathrm{C}$ for 72 hours for estimation of dry matter content. For electrical conductivity test, 10 g seeds of each sample were taken in a conical flask containing $100 \mathrm{ml}$ deionized water and incubated at $20^{\circ} \mathrm{C}$ for 20 hours. After then, the water was decanted and electrical conductivity was measured with a conductivity meter (Model-CM3OET) (Anon., 2006). Four replications of measurements were made for each sample of seeds. The recorded data were properly analyzed and means were separated following DMRT (Zaman et al., 1982).

\section{Results and Discussion}

The percentage of germination was the highest in IPSA Seem-2 (95.67), closely followed by IPSA Seem-5 (92.25\%), and BU Seem-3 was the poorest (88.17\%). The maximum electrical conductivity of seeds was recorded in BU Seem-3 (316.06 $\mu \mathrm{s} / \mathrm{cm})$, which was followed by IPSA Seem-5 $(261.53 \mu \mathrm{s} / \mathrm{cm})$. IPSA Seem-2 was the least $(233.72 \mu \mathrm{s} / \mathrm{cm})$. IPSA Seem-2 scored the maximum vigour index (VI) of seem (65.04), while the other two were statistically similar, having VI values of 35.81 in BU Seem-3 and 38.78 in IPSA Seem-5. Electrical conductivity test provides a quick decision about the seed quality. This test is related to deterioration sequences of seeds, such as degradation of cell membranes and the reduction of respiratory and biosynthetic activities (Delouche and Baskin, 1973). Other factors, such as water quality, period of imbibition, number of seeds tested and temperature also affect electrical conductivity test of seeds (Loefflier et al., 1988; Tao, 1978). IPSA Seem-2 also had the maximum coefficient of germination (CG) (58.90) and the other two were statistically similar but inferior to IPSA Seem -2, having the values 38.43 for BU Seem-3 and 38.92 for IPSA Seem-5 (Table 1). The length of root was statistically the highest for IPSA Seem-5 $(13.73 \mathrm{~cm})$, closely followed by BU Seem-3 $(13.12 \mathrm{~cm})$, which was statistically similar to IPSA Seem-2 $(12.71 \mathrm{~cm})$. IPSA Seem-2 attained the maximum shoot length $(12.98 \mathrm{~cm})$ and the other two were statistically similar, 
but inferior to IPSA Seem-2, having the values $11.96 \mathrm{~cm}$ for BU Seem-3 and $12.09 \mathrm{~cm}$ for IPSA Seem-5 (Table 2). The composite value of dry matter of root and shoot was significantly the highest in IPSA Seem-2 (14.54\%), BU Secm-3 (14.04\%) and LPSA Seem- 5 (13.88\%) were statistically similar, but inferior to IPSA Seem-2 (Table 2).

Seeds harvested from September planting crop had the maximum percentage of germination (95.67\%), closely followed July planting crop (92.00\%). Seeds harvested from May planting crop had minimum percentage of germination (88.42\%). Every delay in sowing was accompanied by production of seeds having significantly higher germination percentage. This might be associated with more favourable humidity condition during seed harvest in case of the plants from delayed sowing. Seeds of early planted crop exhibited the maximum EC (388.23 $\mu \mathrm{s} / \mathrm{cm})$ followed by EC of seeds harvested from July $(240.85 \mu \mathrm{s} / \mathrm{cm})$ and September $(182.23 \mu \mathrm{s} / \mathrm{cm})$ planting crops. The September planting crop had the maximum vigour index (50.07) and coefficient of germination (47.65) followed by July (46.51 and 45.91, respectively) and May planting (43.04 and 42.69, respectively) (Table 1). Seeds of September planted crop on water soaked blotting paper contained in petridish after 8 days had the maximum $13.63 \mathrm{~cm}$ long roots, which was statistically similar to May planted crops $(13.08 \mathrm{~cm})$. The length of root of July planted crop was $12.84 \mathrm{~cm}$. Whereas, after 8 days, the length of shoots was the maximum for May planting crop $(15.29 \mathrm{~cm})$, which gradually reduced with lateness of crop (Table 2). The seedlings grown on blotting paper with seeds harvested from September planting crop exhibited the maximum percentage of dry matter of root $(24.79 \%)$, shoot $(13.34 \%)$, and composite sample (root and shoot) (15.14). These values were found to reduce with earliness of crop. The values for dry matter of root, shoot, and composite sample (root + shoot) of seedlings arose from seeds collected from May and July planted crops were $22.06 \%$ and $22.59 \%, 11.00 \%$ and $12.01 \%$, and 12.96 and $14.36 \%$, respectively (Table 2). Seeds collected from delayed sowing had more robust seedlings, which is also supported by their bigger crown diameter and higher seedling dry weight. Seedling growth is associated with seed size (Austin and Condon, 1967; Bremmer et al., 1963). The linear relationship between seedling dry weight with root $\left(R^{2}=0.9565\right)$ or shoot $\left(R^{2}=0.7860\right)$, dry weight was quite positive (Fig. 1). The higher dry matter of seedling was associated with seeds collected from delayed sowing. The higher dry matter content of seedling indicated the better quality of seeds. 
Table 1. Quality assessment of seeds of three photo-insensitive cultivars of lablab bean obtained from different dates of sowing.

\begin{tabular}{|c|c|c|c|c|c|}
\hline \multicolumn{2}{|c|}{ Treatments } & \multirow{2}{*}{$\begin{array}{l}\text { Germination } \\
\text { (\%) }\end{array}$} & \multirow{2}{*}{$\begin{array}{c}\text { Electrical } \\
\text { conductivity } \\
(\mu \mathrm{s} / \mathrm{cm})\end{array}$} & \multicolumn{2}{|c|}{ Speed of germination } \\
\hline $\begin{array}{l}\text { Date of } \\
\text { sowing }\end{array}$ & Cultivars & & & $\begin{array}{c}\text { Vigour } \\
\text { index (VI) }\end{array}$ & $\begin{array}{c}\text { Coefficient of } \\
\text { germination }\end{array}$ \\
\hline \multirow{3}{*}{15 May } & IPSA Seem-2 & $94.25 \mathrm{ab}$ & $349.08 \mathrm{~b}$ & $57.08 \mathrm{c}$ & $51.08 \mathrm{C}$ \\
\hline & BU Seem-3 & $2.00 \mathrm{c}$ & 369.78 a & $33.42 \mathrm{f}$ & $38.17 \mathrm{~d}$ \\
\hline & IPSA Seem-5 & $89.00 \mathrm{~b}$ & $345.83 \mathrm{~b}$ & 38.62 de & $38.18 \mathrm{~d}$ \\
\hline \multirow[t]{2}{*}{ Mean } & & 88.42 c & 388.23 a & $43.04 \mathrm{c}$ & $42.69 \mathrm{C}$ \\
\hline & IPSA Seem-2 & $95.00 \mathrm{ab}$ & $179.73 \mathrm{f}$ & $67.07 \mathrm{~b}$ & 61.48 b \\
\hline \multirow[t]{2}{*}{15 July } & BU Seem-3 & 89.00 b & $280.20 \mathrm{c}$ & 35.74 ef & $38.21 \mathrm{~d}$ \\
\hline & IPSA Seem-5 & $92.00 \mathrm{ab}$ & $262.61 \mathrm{~d}$ & $36.74 \mathrm{ef}$ & $38.03 \mathrm{~d}$ \\
\hline \multicolumn{2}{|l|}{ Mean } & $92.00 \mathrm{~b}$ & $240.85 \mathrm{~b}$ & $46.51 \mathrm{~b}$ & $45.91 \mathrm{~b}$ \\
\hline \multirow{3}{*}{$\begin{array}{l}15 \\
\text { September }\end{array}$} & IPSA Seem-2 & 97.75 a & $172.34 \mathrm{f}$ & 70.96 a & $64.13 \mathrm{a}$ \\
\hline & BU Seem-3 & 93.5Oab & $198.19 \mathrm{e}$ & 38.28de & $38.92 d$ \\
\hline & IPSA Seem-5 & 95.75 a & $176.15 \mathrm{f}$ & $40.97 \mathrm{~d}$ & $39.90 \mathrm{~d}$ \\
\hline \multirow{2}{*}{\multicolumn{2}{|c|}{$\begin{array}{l}\text { Mean } \\
\text { Mean of cultivars }\end{array}$}} & 95.67 a & $182.23 \mathrm{c}$ & 50.07 a & 47.65 a \\
\hline & & & & & \\
\hline & IPSA Seem-2 & $95.67 \mathrm{a}$ & 233.72 c & $65.04 \mathrm{a}$ & 58.90 a \\
\hline & BU Seem-3 & $88.17 \mathrm{C}$ & 316.06a & $35.81 b$ & $38.43 b$ \\
\hline & IPSA Seem-5 & $92.25 \mathrm{~b}$ & $261.53 \mathrm{~b}$ & $38.78 \mathrm{~b}$ & $38.92 \mathrm{~b}$ \\
\hline \multicolumn{6}{|c|}{ Level of significance } \\
\hline \multicolumn{2}{|c|}{ Date of planting (DP) } & $* *$ & $* *$ & $*$ & $*$ \\
\hline \multicolumn{2}{|c|}{ Cultivar (Cv.) } & $*$ & $* *$ & $* *$ & $* *$ \\
\hline \multicolumn{2}{|c|}{ Interaction (DP x Cv) } & $*$ & $* *$ & $*$ & $* *$ \\
\hline
\end{tabular}

$*$ and $* *$ indicate significant at $5 \%$ and $1 \%$ level of probability

The seeds of the cv. IPSA Seem-2 collected from September planted crops showed the maximum percentage of germination (97.75\%), which was followed by a number of treatments and the minimum percentage of germination was $82.00 \%$ in seeds of cv. BU Seem-3 collected from May planted crops. Seeds of all the cultivars collected from May planted crops showed maximum EC, which gradually reduced with lateness of crop. However, seeds of cv. BU Seem-3 collected from May planted crop had the maximum EC $(469.78 \mu \mathrm{s} / \mathrm{cm})$, which was followed by the rest two cultivars of the same time. In contrast, seeds of all the three cultivars of September planted crop had EC in the range of 172.34 to $198.19 \mu \mathrm{s} / \mathrm{cm}$ ). The seeds of cv. 1PSA Seem-2, irrespective of time of planting of crop showed the maximum vigour index, while BU Seem-3 and IPSA Seem -5 were almost similar statistically. The maximum VI was 70.96 for seeds of cv. IPSA Seem-2 of September planting crop, which was followed by the same cultivar of July (67.07) and May (57.08) planted crop. Figure 2 shows that higher the EC, lower the percentage of germination and the relationship was negative $\left(\left(\mathrm{R}^{2}=\right.\right.$ O.7470). The co-efficient of germination in combined treatments of lablab bean cultivars and date of planting of crop followed the same pattern as of vigour index (Table 1). 
Table 2. Seedling characteristics of seeds of three photo-insensitive cultivars of lablab bean obtained from different dates of plantings.

\begin{tabular}{|c|c|c|c|c|c|c|}
\hline \multicolumn{2}{|c|}{ Treatments } & \multicolumn{2}{|c|}{ Length $(\mathrm{cm})$ of } & \multicolumn{3}{|c|}{ Dry wt (\%) of } \\
\hline $\begin{array}{l}\text { Date of } \\
\text { sowing }\end{array}$ & Cultivars & root & shoot & root & shoot & composite \\
\hline \multirow[t]{3}{*}{15 May } & IPSA Seem-2 & 13.32bc & $16.27 a$ & $21.22 \mathrm{e}$ & $10.21 d$ & $12.43 \mathrm{e}$ \\
\hline & BU Seem-3 & $12.40 \mathrm{~cd}$ & $14.24 \mathrm{c}$ & $22.73 \mathrm{~d}$ & $12.35 \mathrm{c}$ & $14.23 \mathrm{c}$ \\
\hline & IPSA Seem-5 & $13.53 \mathrm{abc}$ & $15.38 \mathrm{~b}$ & $22.23 \mathrm{~d}$ & $10.45 \mathrm{~d}$ & $12.23 \mathrm{C}$ \\
\hline Mean & & $13.08 \mathrm{ab}$ & $15.29 \mathrm{a}$ & $22.06 \mathrm{c}$ & $11.00 \mathrm{C}$ & $12.96 \mathrm{C}$ \\
\hline \multirow[t]{3}{*}{15 July } & IPSA Seem-2 & $11.74 d$ & $11.53 d$ & $23.34 c$ & $12.13 c$ & $14.61 \mathrm{C}$ \\
\hline & BU Seem-3 & 13.73ab & $11.57 d$ & 23.12cd & $11.45 b$ & $13.24 d$ \\
\hline & IPSA Seem-5 & 13.04 be & 10.61 ef & $21.32 \mathrm{e}$ & $12.45 \mathrm{~b}$ & $15.23 \mathrm{~h}$ \\
\hline Mean & & $12.84 \mathrm{~b}$ & 11.24 b & $22.59 \mathrm{~b}$ & $12.01 \mathrm{~b}$ & $14.36 \mathrm{~b}$ \\
\hline \multirow[t]{3}{*}{15 September } & IPSA Seem-2 & 13.06bc & $11.41 \mathrm{de}$ & $24.31 \mathrm{~b}$ & $13.56 \mathrm{a}$ & $16.58 \mathrm{a}$ \\
\hline & BU Seem-3 & 13.22 bc & $10.08 \mathrm{f}$ & $25.19 \mathrm{a}$ & $12.67 \mathrm{~b}$ & $14.64 \mathrm{c}$ \\
\hline & IPSA Seem-5 & 14.63 a & $10.31 \mathrm{f}$ & $24.89 \mathrm{ab}$ & 13.79 a & $14.19 \mathrm{C}$ \\
\hline Mean & & $13.63 \mathrm{a}$ & $10.51 \mathrm{c}$ & 24.79 a & 13.34 a & 15.14 a \\
\hline \multicolumn{7}{|c|}{ Mean of cultivars } \\
\hline & IPSA Seem-2 & $12.71 \mathrm{~b}$ & $12.98 \mathrm{a}$ & $22.95 \mathrm{~b}$ & $11.96 \mathrm{~b}$ & $14.54 \mathrm{a}$ \\
\hline & BU Seem-3 & $3.12 b$ & $11.96 \mathrm{~b}$ & 23.68 a & $12.15 \mathbf{a}$ & $14.04 \mathrm{~b}$ \\
\hline & IPSA Seem-5 & 13.73 a & $12.09 \mathrm{~b}$ & $22.81 \mathrm{~b}$ & $12.26 \mathrm{a}$ & $13.88 \mathrm{~b}$ \\
\hline \multicolumn{7}{|c|}{ Level of significance } \\
\hline \multicolumn{2}{|c|}{ Date of planting (DP) } & $* *$ & $*$ & $*$ & $*$ & $* *$ \\
\hline \multicolumn{2}{|c|}{ Cultivar (Cv) } & ** & $* *$ & $* *$ & $*$ & $* *$ \\
\hline \multicolumn{2}{|c|}{ Interaction (DP x Cv) } & $* *$ & $*$ & $* *$ & * & * \\
\hline
\end{tabular}

$*$ and $* *$ indicate significant at $5 \%$ and $1 \%$ level of probability

Copeland (1976) considered that both coefficient of germination and vigour index as measures of speed of germination. High values of coefficient of germination and vigour index indicate the higher speed of germination. The seeds collected from crops planted at three different times were placed in petridish containing water soaked blotting paper and the length of root and shoot were measured after eight days. The maximum length of root was $14.63 \mathrm{~cm}$ in IPSA Seem-5 when collected from September planting crop, which was followed by a number of treatments and the minimum length of root was $11.74 \mathrm{~cm}$ in IPSA Seem-2 for July planting crop. After eight days of germination of seeds collected from May planting crop, all the cultivars showed higher shoot length than those planted delayed. The dry matter content of root, shoot, and composite (root + shoot) sample of the seedling found to increase gradually with lateness of crop. However, the percentage of dry matter of root of seedling arose from seeds collected from September planting crop ranged from 24.31 to 25.19 and those ranges for seeds collected from the month of July (21.32-23.34\%) and May (21.22-22.73\%). The percentage of dry matter of shoot of seedling, irrespective of cultivars and date of planting of crop followed the same tendency as of dry matter content of root, but it ranged from 10.21 to $13.79 \%$. In contrast, the 
maximum percentage of dry matter of composite sample was 16.58 and the minimum was 12.23 (Table 2).
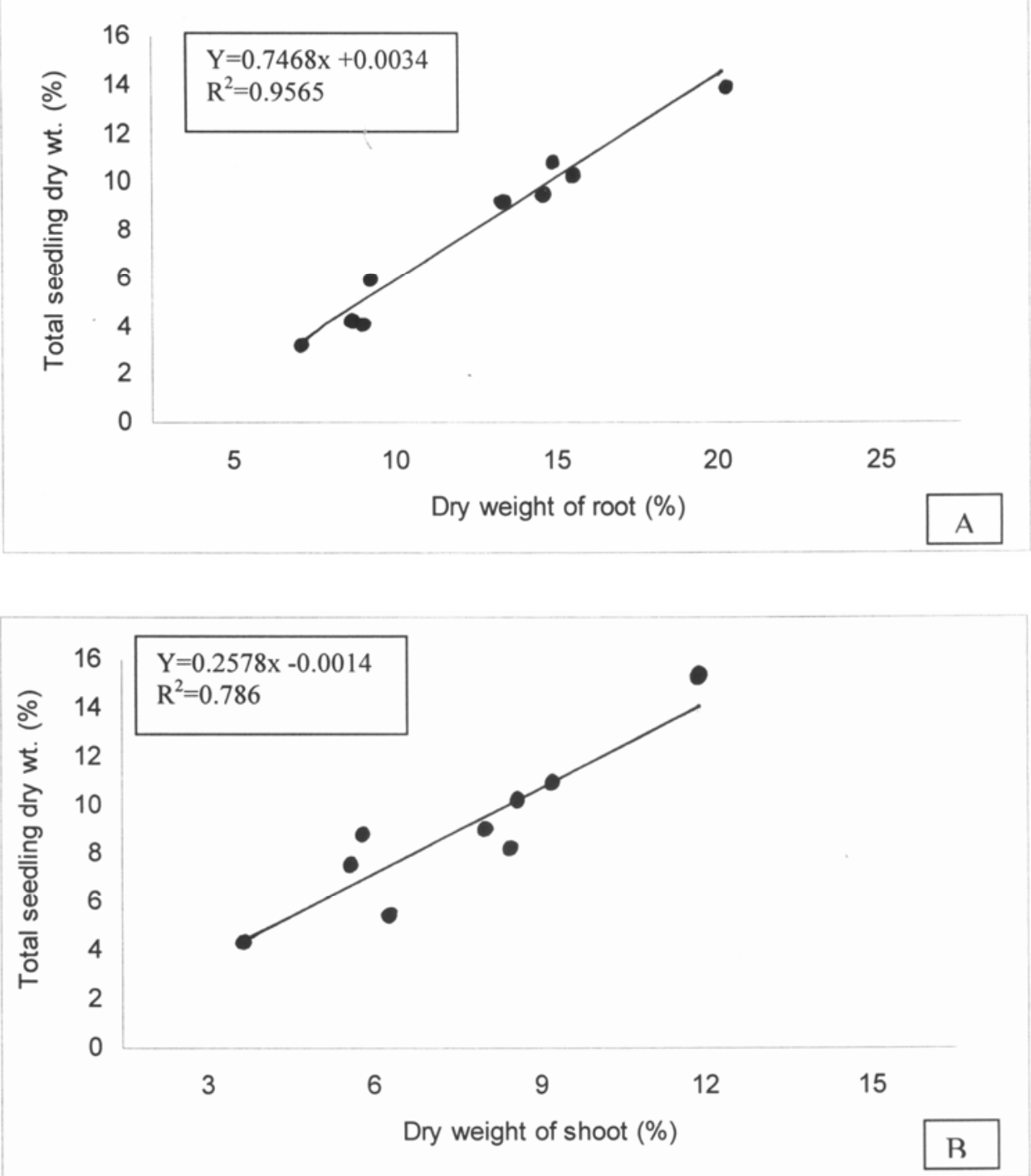

Fig. I. Relationship between total seedling dry weight (\%) with (A) dry weight of root (\%) and (B) dry weight of shoot (\%) of three photo-insensitive cultivars of lablab bean influenced by three dates of sowing. 


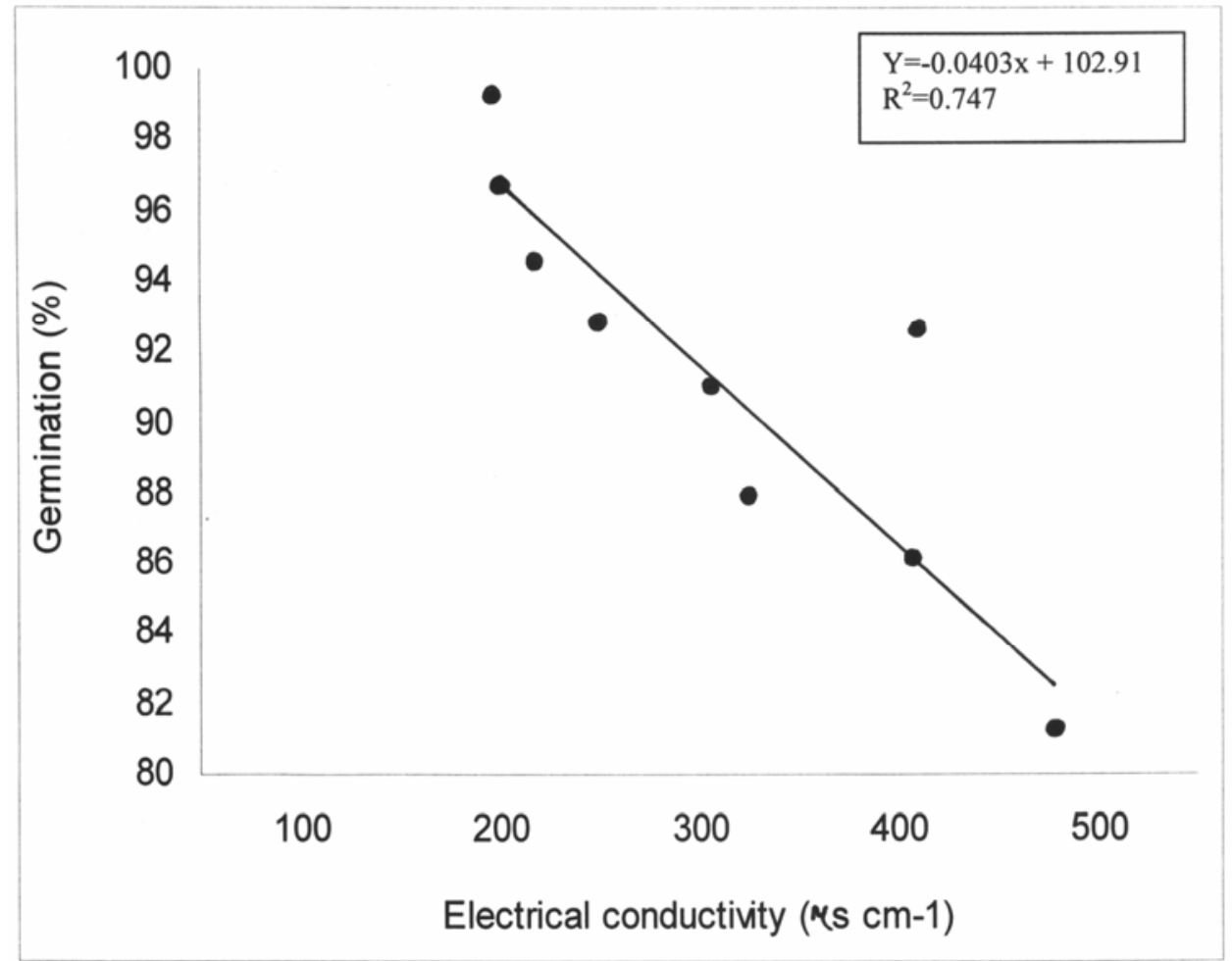

Fig. 2. Relationship between electrical conductivity and germination (\%) of seeds of three photo-insensitive cultivars of bean collected from three sowing dates.

\section{References}

Annonymous. 2007. Agriculture Dairy (in Bengali), Agricultural Information Service, Directorate of Agricultural Extension, Khamarbari, Dhaka.

Annonymous. 2006. Laboratory Equipment Manual. Labtech International, Korea.

BBS. 2005. Year Book of Agricultural Statistics of Bangladesh, Ministry of Planning, Govt. of the People's Republic of Bangladesh. Dhaka. pp. 94-101.

Austin, R.B. and P.C. Condon. 1967. Some effect of seed size and maturity on the yield of carrot crops. J. Hort. Sci. 9: 732-737.

Balles, J., D. Tekrony and D. Egli. 1978. The effect of field production environment as influenced by planting date and cultivars on soybean (Glycine max (L.) M err.). Seed Abstract. 2: 373.

Bremmer, P.M., R.N. Eckersall and H.K. Scott. 1963. The relative importance of embryo size and endosperm size in causing the effects associated with seed in wheat. $J$. Agril. Sci. 61: 139-145. 
Castillo, A.G., J.G. Hampton and P. Coolbear. 1994. Effect of sowing time and harvest timing on seed vigour of garden pea (Pisum sativum L.). Newzealand J. Crop. Hort. Sci. 22: 91-95.

Copeland, L.O. 1976. Principles of Seed Science and Technology. Burgess Pub. Comp., Minnaeapolis, Minnesota, pp. 164-165.

Delouche, J.C. and C.C. Baskin. 1973. Accelerated ageing techniques for predicting the relative storability of seed lots. Seed Sci. Tech. 1: 427-452.

Gopalan, C.V., B.Y.Ramasastri and S.C. Balasubramarium. 1982. Nutritive values of Indian food. National Institute of Nutrition, ICMR, Hyderabad. p.75.

Loeffler, T.M., D.M.Tekrony and D.B. Egli. 1988. The bulk conductivity test as an indicator of soybean seed quality. J. Seed Tech. 12: 37-53.

Srivastava, G.C., D.P.S. Tomar, P.S.Deshmukh and G.S.Sirohi. 1976. Influence of environmental factors due to different sowing dates on yield and oil content in linseed. Indian J. Plant Physiol. 19: 207-2 10.

Tao, K.L.J. 1978. Factors causing variations in the conductivity test for soybean seeds. J. Seed Tech. 3: 10-18.

Zaman, S.M.H., K. Rahim and M. Hawlader. 1982. Simple Lessons from Biometry. Publication no. 54. Bangladesh Rice Res. Inst., pp. 137-171. 